\title{
Bringing Back The Range
}

\section{Innovative land use practices are helping rehabilitate China's Ordos rangelands.}

\author{
By Michael R Frisina, Gu Anlin, Yun Jinfeng, and Bao Weidong
}

A "no mans land" between the ancient cultures of China and Mongolia, the Ordos Plateau has always been a place where cultures mingled and at times clashed. Camel caravans following China's ancient silk route and bound for western markets braved bandits, drought, and unpredictable weather to cross the Ordos rangelands. According to popular legend, during a hunting trip emperor Ghengis Khan ${ }^{1}$ commented on the natural beauty of the Ordos Plateau and expressed his desire to be buried there.

This rich cultural heritage is now intermixed with modern agricultural practices and makes the Ordos Plateau an important farming and livestock producing region of China. Employing innovative land use practices that are compatible with the harsh natural environment is a way of life that has allowed humans to survive on the Plateau for thousands of years.

This long history of intensive use by humans and livestock has caused range deterioration on much of the Ordos Plateau. About 800 years ago during the time of Ghengis Khan, the Ordos was a lush grassland. It was during the Ming and Qing Dynasties that farming was extended across the Ordos and the land was converted to what is presently a sandy desert steppe. Today, China's rangeland conservationists are employing innovative techniques to improve the productivity and biodiversity of the Ordos ranglands.

Most historians believe Ghengis Khan is buried in Outer Mongolia at a location yet to be discovered, but some of his clothes were left in Yijinhuo, Ordos Plateau.

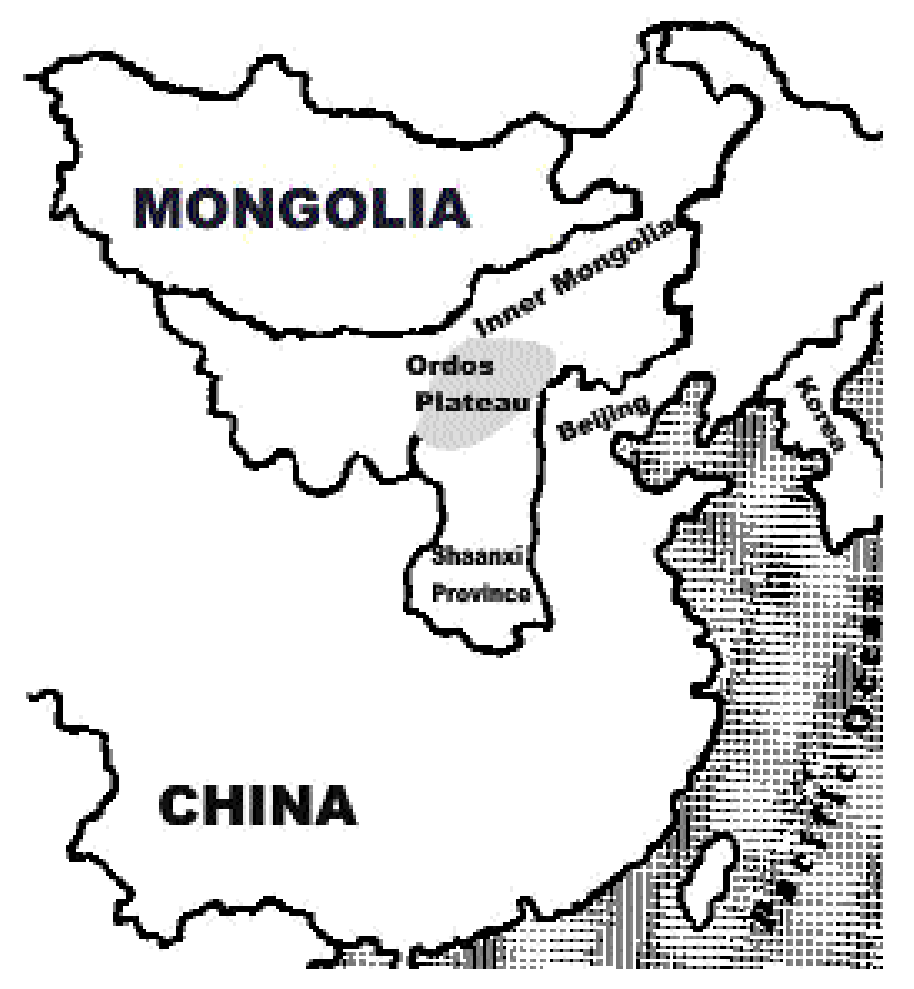

Figure 1. Map illustrating the location of the Ordos Plateau within the Inner Mongolia Autonomous Region and Shaanxi Province of China.

\section{Ordos Is Arid Desert}

The Ordos is a large $(50,200 \mathrm{sq}$. miles) sandy desert plateau located in the southwestern portion of China's Inner Mongolian Autonomous Region and northern Shaanxi Province (Figure 1). Bounded on the south by China's Great Wall and on the north, east, and west by the Yellow River, the Plateau is a unique geographical feature.

The Kubuqi Desert comprises the northern portion of the plateau; the central portion consists of hilly land, and the Maowusu Desert lies in the southern part. There are more than 100 small salt lakes and a few seasonal streams distributed throughout the lower eleva- tions of the Maowusu Desert. Average elevation ranges from a low of 2,800 feet to a high of 7,000 feet.

The Plateau is arid and includes large areas of sandy steppe with an average annual precipitation of 8 to 12 inches. From east to west annual precipitation ranges from 16 to 6 inches. Most moisture comes from July to September. Summers are warm, daytime temperatures average 79 to $82^{\circ} \mathrm{F}$ and can exceed 95 to $100^{\circ} \mathrm{F}$. During winter, January is the coldest month with an average temperature of $12^{\circ} \mathrm{F}$.

The landscape is composed of areas of shrub-grassland $(53 \%)$, woodland $(17 \%)$, cultivated fields $(6 \%)$, and a 


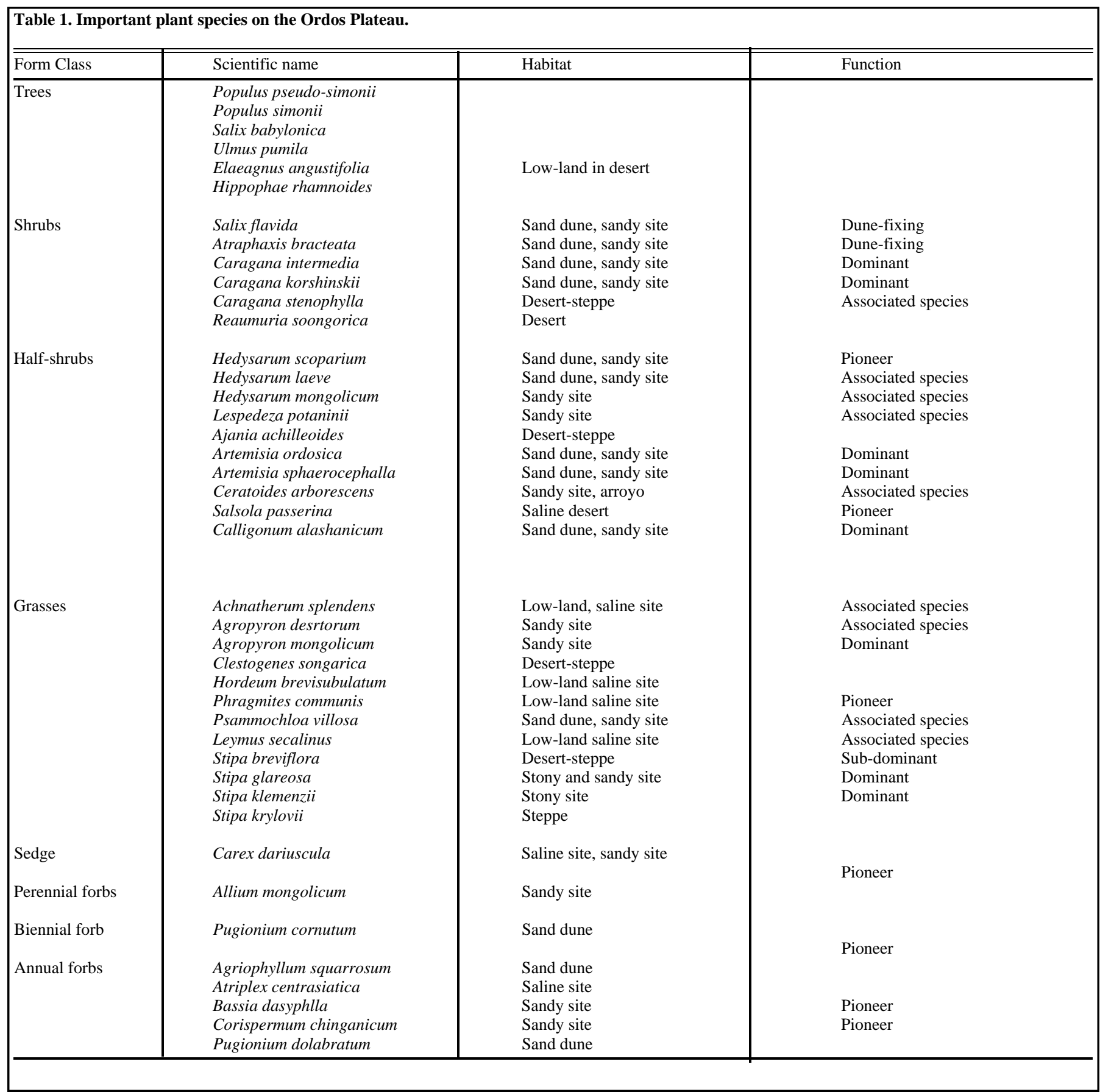

remaining area (24\%) of land nonsuitable for agriculture. These nonsuitable lands include towns, highways, mines and desert without suitable water. Small farmsteads and cultivated fields are interspersed with the native rangeland (Figure 2). Corn, sunflower, millet, potatoes, wheat, and flax are important crops.

The vegetation on Ordos rangelands is typical of arid environments. A diversity of plants are represented by 91 different families, 340 genera, and 647 species. A variety of shrubs, including a number of caraganas and many different types of sagebrush dominate the desert-steppe. Feather grasses and forbs add a diverse appearance to the landscape, in years when there is suitable moisture. In Table 1 the more important native plant species-many important for stabilizing sand dunes are listed by form class.
Wildlife Population Is Diverse

Wildlife species diversity on the Ordos Plateau has not been adequately studied and needs further research. Although wildlife species diversity is less than it was historically due to human disturbance and intensive livestock grazing, there is still a diverse component of mammal and bird species present.

There are 20 key species of mammals that contribute to the character 


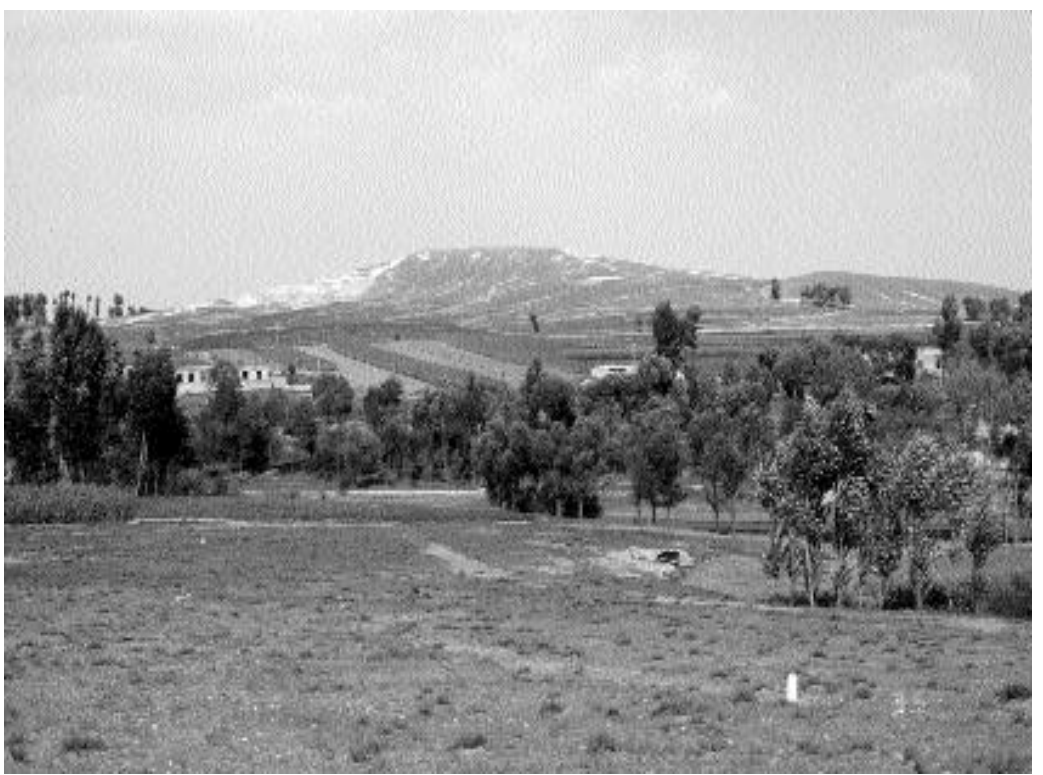

Figure 2. Agricultural lands on the Ordos Plateau are a combination of native rangeland interspersed with small farms producing crops.

\begin{tabular}{|ll|}
\hline $\begin{array}{l}\text { Table 2. Important mammal species known to inhabit } \\
\text { the Ordos Plateau. }\end{array}$ \\
\hline \hline Name & Scientific name* \\
\hline Chinese desert cat & Felis bieti \\
Jungle cat & Felis chaus \\
Red fox & Vulpes vulpes \\
Corsac fox & V. corsac \\
Steppe polecat & Mustela eversmanni \\
Siberian weasel & M. sibirica \\
Marbled polecat & Vormela peregusna \\
Przewalski's gazelle & Procapra przewalskii \\
Mongolia gazelle & P. gutturosa \\
Goitred gazelle & Gazella subgutturosa \\
Brown hare & Lepus capensis \\
Long-eared hedgehog & Hemiechinus auritus \\
Daurian hedgehog & Hemiechinus dauuricus \\
Northern three-toed jerboa & Dipus sagitta \\
Mongolia five-toed jerboa & Allactaga sibirica \\
Midday gerbil & Meriones meridianus \\
Mongolia gerbil & M. unguiculatus \\
Desert hamster & Phodopu roborovskii \\
Striped hamster & Cricetulus barabensis \\
Daurian ground squirrel & Spermophilus dauricus \\
\hline *Taxonomy follows CITES Management Authority of China (ed.) \\
1997.
\end{tabular}

and diversity of the Ordos Plateau (Table 2).

Currently three large ungulate species-Przewalski's gazelle, goitered gazelle, and Mongolia gazelleinhabit Ordos Rangelands in limited numbers. An active program by Chinese rangeland conservationists to stabilize or semi-stabilize vast areas of degraded rangelands is improving habitat conditions for these three species of gazelle.

The rare Chinese desert cat and jungle cat inhabit the more hilly, rugged portions of the plateau. Other small predators like the fox, weasel and polecat are widespread throughout the plant communities of the Ordos Plateau.

A variety of small mammals including the wild hare, northern three-toed jerboa, midday gerbil, desert hamster, Mongolia jerbil, striped hamster and Daurian ground squirrel serve as prey for both avian and mammalian predators. Many of these small mammals have developed unique thermoregulation abilities as adaptations to the desert-steppe environment.

Mammal abundance and species diversity serves as an important environmental quality indicator by which land managers can assess the success of rangeland improvement projects.
There are about 113 main bird species-primarily desert-steppe species-that inhabit the Ordos Plateau (Table 3). There are a variety of wetland species associated with the salt lakes in the Maowusu Desert; and the Taolimiao-Alshan Lake is famous for supporting the largest relict gull breeding population in China.
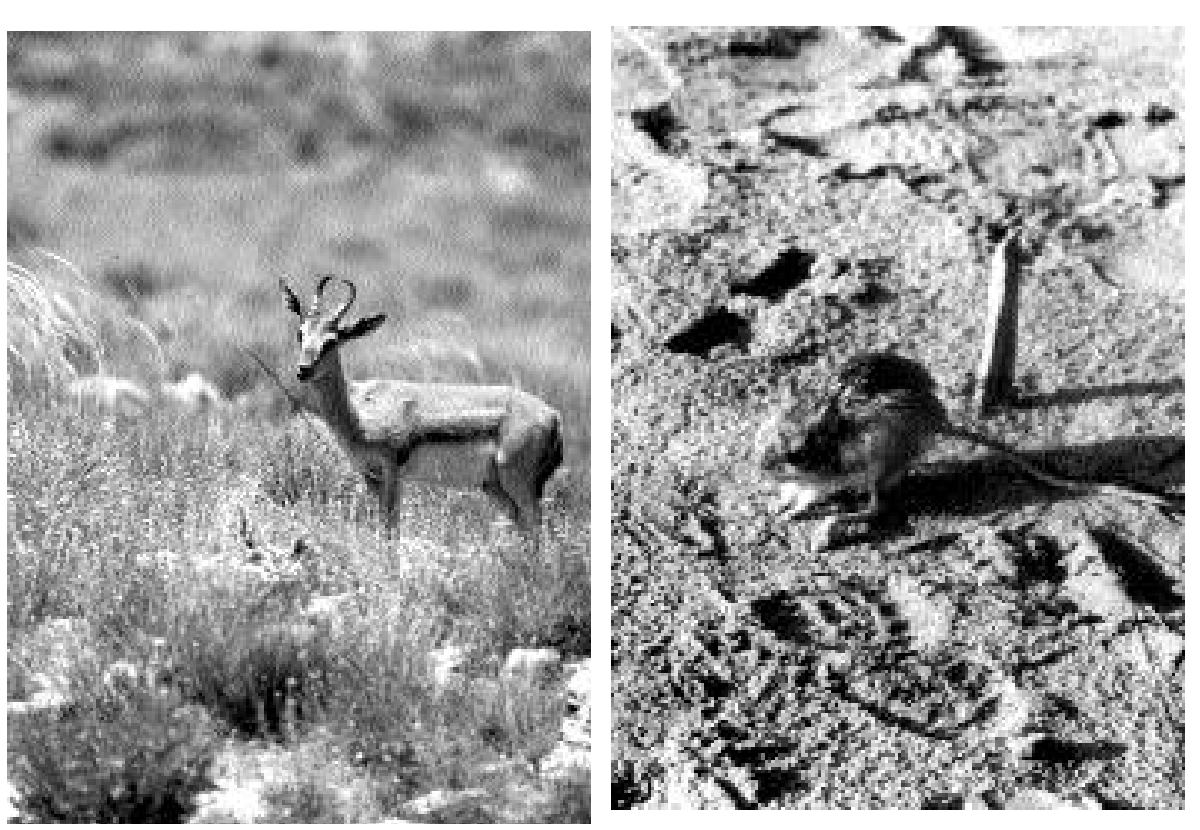

Figure 3. Wildlife diversity on the Ordos Plateau includes the goitred gazelle (left), and the jerboa (right). Gazelle photo courtesy of Raul Valdez.

\section{Sheep \& Goats Dominate}

Domestic livestock currently total nearly 8,000,000 in number. Sheep and goats comprise about $90 \%$ of livestock, pigs 5\%, and cattle, donkeys, camels and horses the remaining 5\%. Family farmsteads derive their livelihood by practicing a mixed agriculture that combines livestock and crop production. This is a community-based 
Table 3. Dominant bird species inhabiting the Ordos Plateau.

\begin{tabular}{|c|c|c|c|}
\hline Little grebe & Podiceps ruficollis & Blue hill pigeon & Columba rupestris \\
\hline Black-necked grebe & P. nigricollis & Collared turtle dove & Streptopelia decaocto \\
\hline Great crested grebe & P. cristatus & Common cuckoo & Cuculus canorus \\
\hline Common cormorant & Phalacrocorax carbo & Little owl & Athene noctua \\
\hline Grey heron & Ardea cinerea & Long-eared owl & Asio otus \\
\hline White spoonbill & Platalea leucorodia & Eagle owl & Bubo bubo \\
\hline Swan goose & Anser cygnoides & Large white-rumped swift & Apus pacificus \\
\hline Bean goose & A. fabalis & Hoopoe & Upupa epops \\
\hline Greylag goose & A. anser & Wryneck & Jynx torquilla \\
\hline Whooper swan & Cygnus cygnus & Greater pied woodpecker & Picoides major \\
\hline Ruddy shelduck & Tadorna ferruginea & Mongolian skylark & Melanocorypha mongolica \\
\hline Common shelduck & T. tadorna & Short-toed lark & Calandrella cinerea \\
\hline pintail & Anas acuta & Hume's short-toed lark & C. acutirostris \\
\hline Common teal & A. crecca & Asian short-toed lark & C. cheleensis \\
\hline Falcated teal & A. falcata & Crested lark & Galerida cristata \\
\hline mallard & A. platyrhynchos & Skylark & Alauda arvensis \\
\hline Spotbill duck & A. poecilorhyncha & Horned lark & Eremophila alpestris \\
\hline Gadwall & A. strepera & Golden-rumped wallow & Hirundo daurica \\
\hline wigeon & A. penelope & House swallow & H. rustica \\
\hline garganey & A. querquedula & Crag martin & H. rupestris \\
\hline shoveller & A. clypeata & Sand martin & Riparia riparia \\
\hline Red-crested pochard & Netta rufina & Yellow-headed wagtail & Motacilla citreola \\
\hline Common pochard & Aythya ferina & Grey wagtail & M. cinerea \\
\hline White-eyed pochard & A. nyroca & White wagtail & M. alba \\
\hline Golden-eyed pochard & Bucephala clangula & Oriental tree pipit & Anthus hodgsoni \\
\hline smew & Mergus albelus & Red-tailed shrike & Lanius cristatus \\
\hline Black kite & Milvus migrans & Red-backed shrike & L. collurio \\
\hline Cinereous vulture & Aegypius monachus & Long-tailed grey shrike & L. sphenocercus \\
\hline Eastern marsh harrier & Circus spilonotus & Black drongo & Dicrurus macrocercus \\
\hline Upland buzzard & Buteo hemilasius & Magpie & Pica pica \\
\hline White tailed sea eagle & Haliaeetus albicilla & Red-billed chough & Pyrrhocorax pyrrhocorax \\
\hline Pallas's sea eagle & H. leucoryphus & Yellow-billed chough & P. graculus \\
\hline Golden eagle & Aquila chrysaetos & Thick-billed crow & Corvus macrorhynchos \\
\hline Steppe eagle & A. rapax & Daurian jackdew & C. dauuricus \\
\hline Red-legged falcon & Falco vespertinus & Black redstart & Phoenicurus ochruros \\
\hline Lesser kestrel & F. naumanni & Daurian redstart & P. auroreus \\
\hline Common kestrel & F. tinnunculus & Stone chat & Saxicola torquata \\
\hline Coot & Fulica atra & Desert wheatear & Oenanthe deserti \\
\hline Lapwing & Vanellus vanellus & Pied wheatear & O. hispanica \\
\hline Gray-headed lapwing & V. cinereus & Wheat ear & O. oenanthe \\
\hline Chukor partridge & Alectoris chukar & Isabelline wheat ear & O. isabellina \\
\hline Daurian partridge & Perdix daunricae & White-backed rock thrush & Monticola saxatilis \\
\hline Common quail & Coturnix cotunix & Dusky willow warbler & Phylloscopus fuscatus \\
\hline Common pheasant & Phasianus colchicus & Long-tailed tit & Aegithalos caudatus \\
\hline Demoiselle crane & Anthropoides virgo & Medow bunting & Emberiza cioides \\
\hline Great bustard & Otis tarda & Rock bunting & E. cia \\
\hline Eastern golden plover & Pluvialls dominica & Little bunting & E. pusilla \\
\hline Little ringed plover & Charadrius dubius & Green finch & Carduelis sinica \\
\hline Kentish plover & Ch. Alexandrinus & Pallas's sandgrouse & Syrrhaptes paradoxus \\
\hline Curlew & Numenius arquata & & \\
\hline Black-tailed godwit & Limosa limosa & & \\
\hline Common redshank & Tringa totanus & & \\
\hline Ruddy turnstone & Arenaria interpres & & \\
\hline Fantail snipe & Capella gallinago & & \\
\hline Black-winged stilt & Himantopus himantopus & & \\
\hline Pied avocet & Recurvirostra avosetta & & \\
\hline Mew gull & Larus canus & & \\
\hline Herring gull & L. argentatus & & \\
\hline Great black-headed gull & L. ichthyartus & & \\
\hline Relic gull & L. relictus & & \\
\hline Black-headed gull & L. ridibundus & & \\
\hline Whiskered tern & Chlidonias hybrida & & \\
\hline Gull-billed tern & Gelochelidon nilotica & & \\
\hline Common tern & Sterna hirundo & & \\
\hline
\end{tabular}



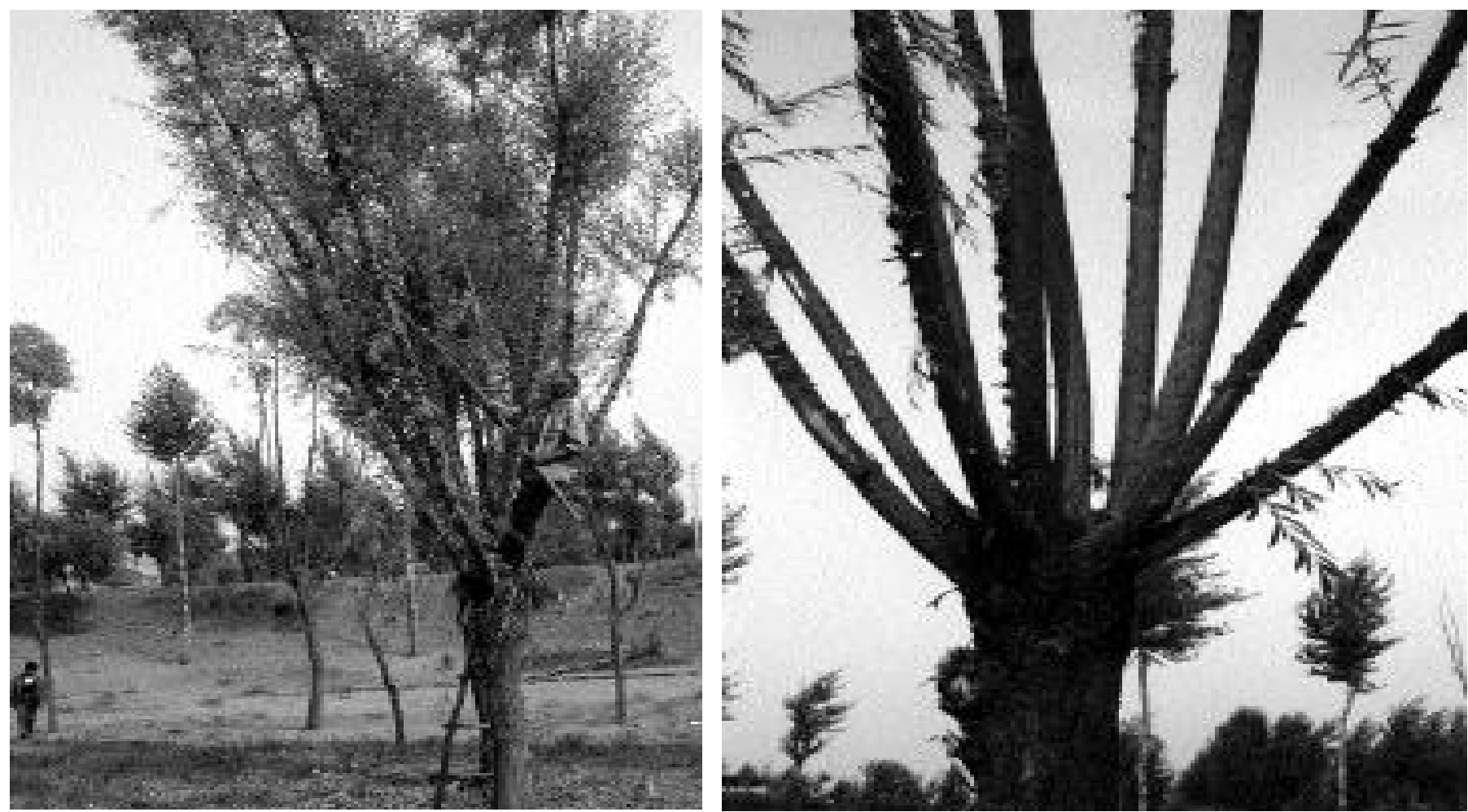

Figure 4. Green banking is an important form of sustainable agriculture on the Ordos Plateau. In the left photo the worker is pruning stems of the current years growth to be used as winter livestock forage. The right photo shows the effects of several years pruning. These heavy stems will eventually be used as lumber for home construction.

agriculture involving close cooperation between family members and village members.

Farms vary in size depending on their primary activity_farming or livestock production. In farming areas each family will grow crops on 35 to 50 acres and raise 20 to 30 goats and sheep. In pasture areas each family has 250 to 400 acres for raising 100 to 150 goats and sheep. The land base usually includes 30 to 50 acres planted as forage crops and to aid in sanddune control and lumber production.

\section{Two Important Land Use \\ Practices}

1) Green banking-Stockmen have developed an environmentally friendly and very practical means of producing winter forage for livestock. They call this approach green banking, it also allows for the production of wood beams for house construction, and orchards of trees for soil stabilization and beautification along the edges of fields and highways.
Willow trees are planted and periodically pruned.The trees are pruned in late summer at about the same time

stockmen on western rangelands are harvesting hay. The cuttings are stored and used as winter livestock forage.

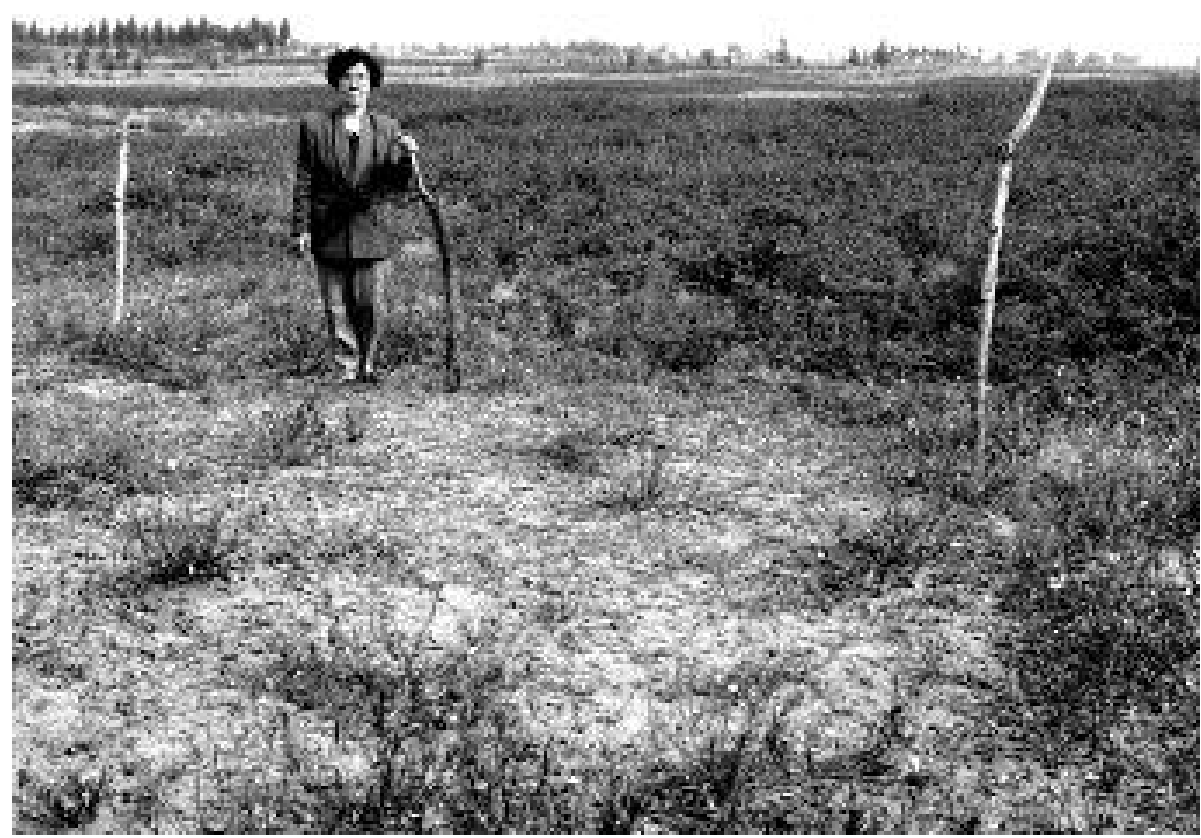

Figure 5. Legumes are planted as a means of improving degraded rangelands and stabilizing the sandy Ordos soils. Behind author Yun Jinfeng is a successful planting of legumes. Prior to planting the site looked similar to the photo foreground. 


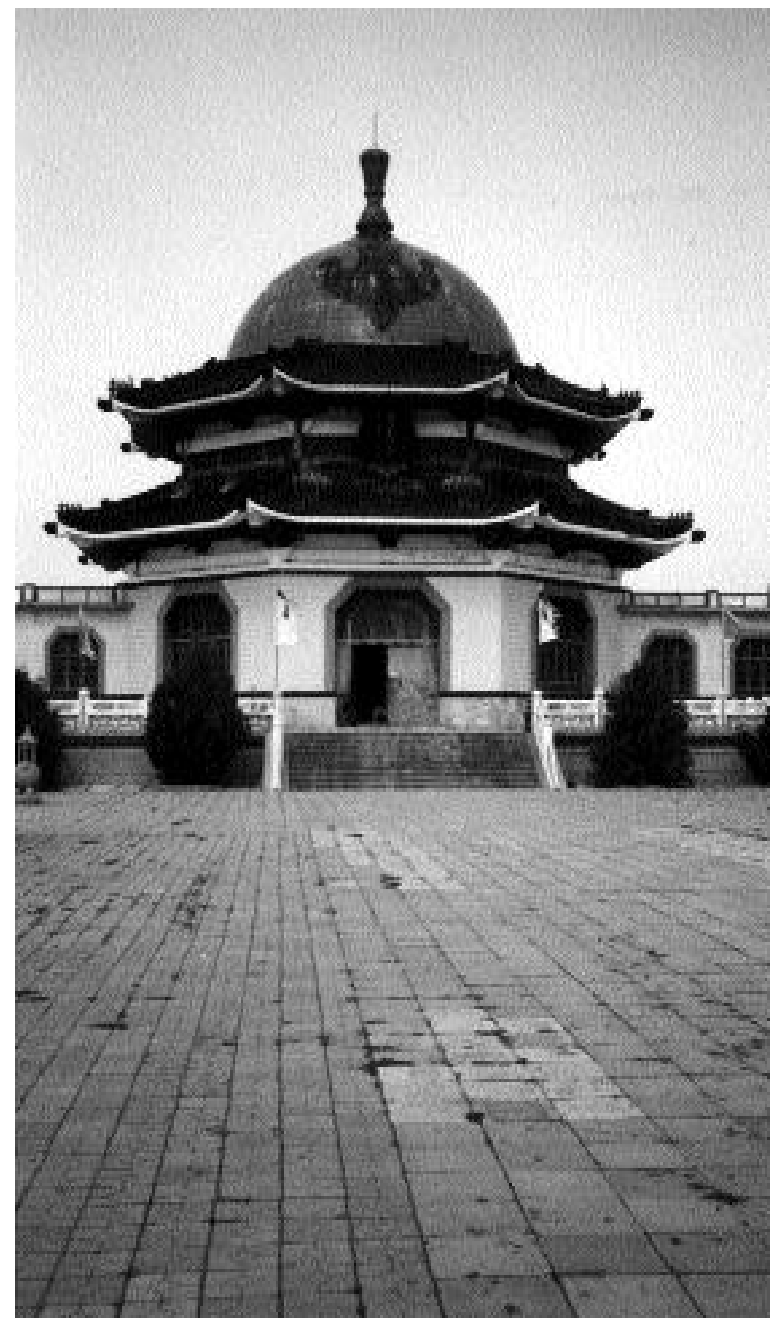

Figure 6. In the city of Dong Sheng, a memorial commem orates the traditional nomadic herder lifestyle of the Ordos Plateau.

This pruning is done in a way that promotes the growth form illustrated in Figure 4. The multiple stems protruding from the main tree trunk are periodically trimmed into poles and used for house construction. The poles make suitable beams for the roof structure of adobe homes - a unique and environmentally friendly way to utilize products essential for human survival in a demanding environment. Such a method of obtaining resources is not new to the people of the Ordos who, for thousands of years, have had to adapt in a way that is compatible with their harsh arid environment.

2) Sandy Soil Stabilization-The sandy desert soils and frequent high winds typical of the Ordos Plateau create a very unstable rangeland situa- tion. In areas that are either naturally unstable or have lost their stability from historic intensive livestock grazing, rangeland specialists are aggressively planting species that are capable of stabilizing soils and are also useable as livestock forage. Some of these plantings are done aerially and have been quite successful as illustrated in Figure 5. Since the 1970's several different species of legumes (pea family) have been planted successfully.

These two techniques, recently employed by China's Northwestern Ecological Environmental Protection Project, are helping improve the environment and rehabilitate degraded rangelands. These efforts are not only improving the sustainability of agriculture, but are also allowing for improved biodiversity on the Ordos Plateau.

The Ordos Plateau has a long record of human history going back at least 5,000 years. The lifestyle is tied to the land, with people as much a part of the landform as their domestic animals and the plants that give life to all. This lifestyle is commemorated in the Ordos city of Dong Sheng where a magnificent memorial to the Mongol nomadic tribes and their culture stands as a symbol of man's enduring tie to the land (Figure 6). We all can learn from the practitioners of land management on the Ordos Plateau.

Michael R. Frisina is Range Coordinator with Montana Fish, Wildlife \& Parks, 1330 West Gold Street, Butte, MT. 59701.

Gu Anlin is Grassland Research Scientist Inner Mongolian Grassland Research, Institute, Chinese Academy of Agricultural Sciences, Huhehot, Inner Mongolia, P. R. China.

Yun Jinfeng is a Professor, Department of Grassland Science, Inner Mongolia College of Agriculture and Animal Husbandry,
Huheot, Inner Mongolia, P. R. China.

Bao Weidong is Associate Professor, College of Forest Resources and Environment, Beijing Forestry University, Bejing, P.R. China.

\section{References}

CITES Management Authority of China (ed.). 1997. Distribution of Mammalian Species in China. Forestry Publishing House, Beijing, China.

Cleaves, F.W. (editor). 1982. The secret history of the Mongols: For the first time done into English out of the original tongue. Harvard Univeristy Press, Cambridge Massachusets and London, England.

Editorial Board of "Annals of Yikezhao League". 1994. Annals of Yikezhao League, Contemporary Press, Beijing, China.(Chinese language)

Expedition team to the Maowusu Desert. 1976. Experience and problems on sand dune-fixing and afforestation in the Maowusu Desert. In Controlling of Desert. Science Press, Beijing, China. (Chinese language)

He Fenqi, Zhang Yinsun, Ye Enqi, Wu Yong, Chen Rongbo. 1996. Study on the wetland bird community and assessment on wetland habitat of the TaolimiaoAlashan Nur in Ordos of Inner Mongolia, China. Chinese Biodiversity 4:187-193.

Lattimore, O. 1941. Mongol Journeys. Alden Press, Oxford, England.

Scientific expedition team to Inner Mongolia, Ningxia. 1985. Vegetation of Inner Mongolia. Science Press, Beijing, China. (Chinese language)

Yang Guisheng, Xing Lianlian, Yan Chongwei. 1999. The transition feature for the bird fauna of the desert steppe and steppificated desert district in NeiMongol. Acta Scientiarum Naturalim Universitatis NeiMongol. 30:636-639.

Yang Guisheng, Xing Lianlin. 1998. Terrestrial Vertebrate Regionalization of NeiMongol. Acta Scientiarum Naturalim Univeritatus NeiMongol 29:806-811. 